\title{
Sulfate attack and embedded steel corrosion resistances of volcanic-aggregate concrete with fly ash and silica fume
}

\author{
Abaho G. Gershome ${ }^{a^{*}}$, Mutabaruka Jean de Dieu ${ }^{\mathrm{b}}$, Mbereyaho Leopold $^{\mathrm{c}}$ \\ ${ }^{\text {a,b,c }}$ University of Rwanda, College of Science and Technology, School of Engineering, \\ Department of Civil, Environmental and Geomatics Engineering, Rwanda. \\ *Corresponding author: Email: abaho12345@yahoo.com
}

\begin{abstract}
Construction materials are increasingly on high demand in the developing world. The construction industry has a challenge of discovering, new alternative construction materials to conventional materials which are locally available materials in environmentally friendly manner. The experimental tests are conducted on volcanic concrete system to analyze its properties especially corrosion resistance potential for its applicability in construction. The major aim is to investigate its suitability and corrosion resistance potential especially when used in construction of structures with embedded steel. The test results of the material show that volcanic concrete system with $30 \%$ fly ash and $10 \%$ silica fume cementing materials is an alternative green construction material. Permeability properties are reduced by $8 \%$ and $24 \%$ with $30 \%$ fly ash and $10 \%$ silica fume respectively. Tests also indicate that Compressive strength, Corrosion potential and polarization resistance in volcanic concrete system with supplementing cement materials has more potential to resist sulfate attack when compared with conventional volcanic concrete systems. The supplementary cementing materials $(\mathrm{SCM})$ reduce the pore system
\end{abstract}


and hence decrease the ingress of corrosive ions and water in concrete. Corrosive ions, moisture and air would initiate corrosion to the embedded steel in concrete leading to reduced service life such structures.

Key word: Supplementary Cementing Materials, Sulfate attack, volcanic concrete system, Granite powder, river sand, Corrosion of embedded steel

\section{Introduction}

The main function of concrete cover is to protect reinforcement in order to minimize its corrosion from environmental effects. However, corrosion of embedded steel has significantly affected the performance of concrete structures, especially those with long designed service life. Corrosion of embedded steel in concrete is usually due to porous nature of concrete, which paves the way for ingress of corrosive elements. When moisture, air and corrosive ions penetrate concrete up to the embedded steel surface, there is a high risk of corrosion initiation. The ingress of different species depends on the porous nature of concrete or else on other defects like cracks and the quality of the materials that compose the concrete. This shortens the service life of -concrete structures but also negatively affect the environment and in general, retards the sustainable development (Jungle et al.2011; Schneider et al. 2011; Shi et al. 2011). Among other factors, concrete deteriorates due to sulfate attack by expansion effect. Researchers have suggested alternative concrete material ingredients from various sources for different applications. Waste industrial materials and granite powder can be used as alternative fine aggregates to natural sand in concrete mixes Halifax et al. (2009). Quarry waste and Lime stone dust, siliceous stone rock powder, are examples of materials used as an alternative 
to natural fine aggregates (Halifax et al. 2009). The utilization of locally available materials like volcanic rock aggregates was recommended by various researchers (Abaho and Pranesh (2016); Schittich (2012); Red DURAR (1998). Porosity in concrete sooner or later can lead to both steel cover deterioration and embedded steel corrosion Rasheed uzzafar et al. (1990). The sulfate permeation can be minimized by: increasing concrete compactness, use of low water-to-cement ratio, proper curing, surface treatment, and use of precast concrete than cast-in-situ concrete as proposed by ACI Committee (1991); Hossain (2004); Kalousek et al. (1972); Al-Amoudi et al. (1994); Young et al. (1998). Irassar et al. (2000) found that cements with low $\mathrm{C}_{3} \mathrm{~S} / \mathrm{C}_{2} \mathrm{~S}$ ratio have low resistance to sulfate attack. Researchers like Rasheed uzzafar (1990); Kalousek et al. (1972); Lawrence (1990); found that tri calcium aluminate $\left(C_{3} A\right)$ content is not the major reason for sulfate attack in concrete. Mehta (1993) concluded that Type V cement cannot resist the initiation of sulfate expansion in concrete. It is more useful when calcium sulfate is the slate to concrete medium; it is again effective in prevention of gypsum owing sodium sulfate attack. Neville (2004) observed that significant progress has been made with regards to the mechanism of sulfate attack in concrete, however, he stated that its knowledge and full understanding remains inadequate. It is still not clear whether tri calcium aluminate, water content and pozzolanic material has a significant role in sulfate attack. Performance evaluation of the SCMs in volcanic concrete system mix with granite powder to sulfate attack resistance and corrosion of embedded steel in concrete is a potential area of research. In this study, a volcanic concrete system has been developed with locally available materials of volcanic rock aggregates (VRA), granite powder, partly replacing river sand (RS) and Fly ash and silica fume as Supplementary Cementing 
Materials (SCM). This paper intends to investigate the resistance potential to both sulfate attack and corrosion initiation of a concrete system produced with concrete mix ingredients mentioned above.

\section{Materials and Methods}

Table 1 Mix Design with Mix Proportions

\begin{tabular}{|c|c|c|c|c|c|c|}
\hline No & $\begin{array}{l}\text { Designation } \\
\text { of Mix }\end{array}$ & $\begin{array}{l}\text { Volcanic Rock } \\
\text { coarse } \\
\text { aggregate } \\
\quad(\%)\end{array}$ & $\begin{array}{l}\text { River Sand } \\
\text { fine aggregate (RS) } \\
\text { (\%) }\end{array}$ & $\begin{array}{l}\text { Replacement } \\
\text { for river sand } \\
\text { by granite } \\
\text { powder (\%) }\end{array}$ & $\begin{array}{l}\text { Cement } \\
\text { (\%) }\end{array}$ & $\begin{array}{l}\text { Replacement } \\
\text { for Cement } \\
\text { (\%) }\end{array}$ \\
\hline \multicolumn{7}{|c|}{$\begin{array}{l}\text { The original mixing ratio of volcanic coarse, fine and cement concrete was 1:2:4 before replacement. } \\
\text { The } 30 \% \text { granite powder in replacement of river sand fine aggregate is appropriate, Abaho and } \\
\text { Pranesh (2016) }\end{array}$} \\
\hline 1 & $\begin{array}{l}\text { Compound } \\
\text { Portland Cement } \\
\text { (CPC) }\end{array}$ & 100 & 70 & 30 & 100 & 0 \\
\hline 2 & Fly Ash (FA) & 100 & 70 & 30 & 70 & 30 \\
\hline 3 & $\begin{array}{l}\text { Silica Fume } \\
\text { (SF) }\end{array}$ & 100 & 70 & 30 & 90 & 10 \\
\hline
\end{tabular}

The study conducted tests and experimental setups in three sets. The aggregates were $100 \%$ volcanic coarse aggregates along with $30 \%$ granite powder in replacement of river sand fine aggregates: One set was produced with $100 \% \mathrm{CPC}$; another set was made with $30 \%$ FA in partial replacement of CPC, and finally, another set was made with $10 \% \mathrm{SF}$ in partial replacement of PCC. These specimens were cured for 28 days in a chamber with temperature of $28 \pm 2^{0} \mathrm{C}$ and $98 \pm 1 \%$ of relative humidity.

\subsection{Concrete materials}

The materials used were basically from Rwanda except Silica fume and Fly-Ash which were sourced from India. Compound Portland cement is manufactured from chalk, clay and gypsum is added to the clinker, when hardened resembles Portland stone hence the 
name. Grade 43 Compound Portland Cement (cement manufactured Rwanda), purified drinking water, volcanic rock aggregates from Ruhengeri-Northern province, Kagugu river sand and granite rock powder from East Africa granite plant at Nyagatare in the eastern province used as fine aggregates and silica fume as supplementary cementing material were the materials used. The result of sieve analysis for the coarse and fine aggregates in Tables 2 and Figure 1, the results of the tests for the chemical properties of the cementing materials, and aggregates in Table 4 to 7 presented in this paper are part of generated data in the previous published research paper Abaho and Pranesh (2016). With sieve analysis, crushed volcanic rock aggregates size were in the range between $20 \mathrm{~mm}$ to $6.3 \mathrm{~mm}$ while the size of fine aggregates used ranged between $4.75 \mathrm{~mm}$ to $150 \mathrm{micro}$. The bigger size of volcanic rock coarse aggregate used was $19 \mathrm{~mm}$. Table 2 shows sieves analysis results for coarse aggregates.

Table 2 Sieve Analysis results of coarse aggregates.

\begin{tabular}{ccc}
\hline No & Sieve Size (mm) & $\begin{array}{c}\text { Percentage } \\
\text { Passing }\end{array}$ \\
\hline 1 & 25 & 100 \\
2 & 20 & 98 \\
3 & 16 & 87 \\
4 & 12.5 & 64 \\
5 & 10 & 26 \\
6 & 6.3 & 03 \\
7 & 4.75 & 00 \\
\hline
\end{tabular}

The results obtained after conducting sieve analysis for both granite fine aggregate as compared with natural sand (river sand) are shown Fig 1. 


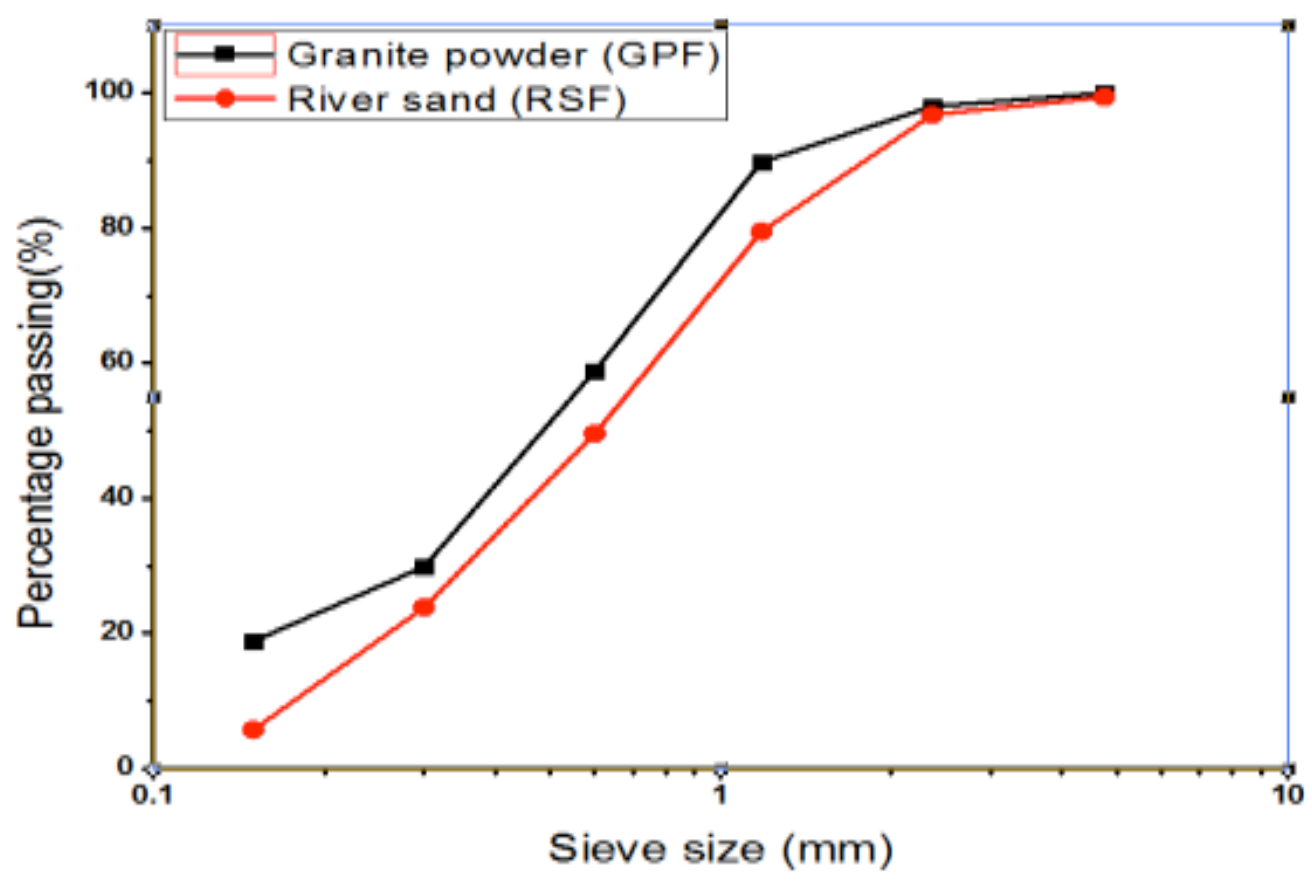

Figure 1 Sieve analysis of fine aggregates

It was considered important to properly proportion the materials used in the concrete mix which was done as shown in Table 3.

Table 3 -Mix design (by $1 \mathrm{~m}^{3}$ of concrete)

\begin{tabular}{|c|c|c|c|}
\hline \multirow{2}{*}{$\begin{array}{c}\text { Materials } \\
(\text { Kg) }\end{array}$} & $\begin{array}{c}|c| \\
\text { VRA- 30\%GPF } \\
\mathbf{1 0 0} \% \mathbf{C P C}\end{array}$ & $\begin{array}{c}\text { VRA 30\%GPF } \\
\mathbf{3 0 \%} \mathbf{~ F A}\end{array}$ & $\begin{array}{c}\text { VRA 30\%GPF } \\
\mathbf{1 0 \%} \text { SF }\end{array}$ \\
\hline Water & 213.31 & 213.31 & 213.31 \\
\hline Cement & 444.44 & 444.44 & 400.00 \\
\hline RSF & 915.35 & 640.745 & 640.745 \\
\hline GPF & 0.000 & 274.605 & 274.605 \\
\hline VCA & 870.58 & 870.58 & 870.58 \\
\hline SCM & 0.000 & 0.000 & 44.44 \\
\hline \multicolumn{2}{|c|}{ Super Plasticizer 1\% of cement mass was used in the mix } \\
\hline
\end{tabular}

For better proportioning of fine aggregates to coarse aggregates ratio, particle size for both coarse and fine aggregates was graded. For conformity with grading limit (IS: 383197), the granite aggregate fall in zone II of crushed aggregate and river sand aggregates 
fall in zone II grading limit of fine aggregates. The surface index method helps in the proportioning of fine to coarse aggregates (Murdock and L. J (1960). Table 4, 5, 6 and 7 presents both the physical and chemical properties of the materials used.

Table 4 Chemical properties of the aggregates used in concrete mixtures

\begin{tabular}{|c|c|c|}
\hline No & Materials & Description \\
\hline \multicolumn{3}{|r|}{ Physical properties of aggregates and super plasticisers } \\
\hline 1 & $\begin{array}{l}\text { Volcanic rock } \\
\text { aggregate }\end{array}$ & $\begin{array}{l}\text { Specific gravity-2.42-2.7, Fine modulus- } 2.43 \text {,Mamum size- } 19 \mathrm{~mm} \text {, Bulk } \\
\text { Density(Kg/lit)- Loose - } 1.216 \text {, rounded }-1.360\end{array}$ \\
\hline 2 & Rive & $\begin{array}{l}\text { Specific gravity-2.58, Fine modulus- } 2.43 \text {, Humidity Module }(\%)-6.66 \text {, } \\
\text { Fineness Module }(\%)-2.73 \text {, Relative density }(\mathrm{g} / \mathrm{cm} 3)-2.43 \text {, Absorption } \\
(\%)-0.44 \text {, Particle size range from less than } 0.25 \mathrm{~mm}-6.3 \mathrm{~mm} \\
\text { Maximum size module }(\%)-6.3 \text {, Humidity }(\%)-0.28\end{array}$ \\
\hline 3 & Granite powder & $\begin{array}{l}\text { Specific gravity-1.220-2.6, Soundness ( } \% \text { by mass after } 5 \text { cycles) Sodium } \\
\text { sulphate - } 4.86 \text {, Magnesium sulphate-5.48, Fine modulus- } 2.43 \text {, water } \\
\text { Absorptio (\%)-13, }\end{array}$ \\
\hline 4 & superplasticisers & $\begin{array}{l}\text { Specific gravity-, Chloride content-Nil , Recommended dosage- } 2-4 \% \text { of } \\
\text { cement, Air attrainment- } 1 \% \text { at normal dosage, solid content- } 40 \% \text {, } \\
\text { operating temperature-(10-40) }{ }^{\circ} \mathrm{C}, \text { Compatibility- All types of cement } \\
\text { except high allumina cement }\end{array}$ \\
\hline
\end{tabular}

Table 5 Chemical properties of Aggregates: (Chemical composition in \% by mass) 


\begin{tabular}{|c|c|c|c|c|c|c|c|c|}
\hline Material & $\mathbf{S i O}_{2}$ & $\mathbf{A l O}_{3}$ & $\mathbf{F e}_{2} \mathbf{O}_{3}$ & $\mathbf{C a O}$ & $\mathbf{S O}_{3}$ & $\mathbf{K}_{\mathbf{2}} \mathbf{O}$ & $\mathbf{N a}_{2} \mathbf{O}$ & $\mathbf{M g} \mathbf{O}$ \\
\hline VCA & 59.42 & 12.36 & 5.99 & 4.63 & 0.007 & - & - & 1.81 \\
\hline GPF & 19.94 & 4.40 & 0.82 & 3.18 & 0.05 & 0.42 & & - \\
\hline
\end{tabular}

Table 6 Chemical properties of cementing materials

\begin{tabular}{|l|l|l|l|l|l|l|l|l|}
\hline \multicolumn{9}{|c|}{ Chemical composition (\%of weight) } \\
\hline Material & $\mathbf{S i O}_{\mathbf{2}}$ & $\mathbf{A l}_{\mathbf{2}} \mathbf{O}_{\mathbf{3}}$ & $\mathbf{F e}_{\mathbf{2}} \mathbf{O}_{\mathbf{3}}$ & $\mathbf{C a O}$ & $\mathbf{S O}_{3}$ & $\mathbf{K}_{\mathbf{2}} \mathbf{O}$ & $\begin{array}{l}\mathbf{N a}_{2} \\
\mathbf{O}\end{array}$ & $\mathbf{M g O}$ \\
\hline CPC & 19.94 & 4.40 & 2.97 & 63.50 & 3.08 & 0.42 & 0.12 & - \\
\hline FA & 58.84 & 16.72 & 3.52 & 7.35 & 0.13 & 0.79 & 0.94 & 1.76 \\
\hline SF & 95.22 & 0.08 & 2.37 & 0.26 & 0.11 & 0.56 & 0.30 & 0.24 \\
\hline
\end{tabular}

Table 7 Physical properties of cementing materials

\begin{tabular}{|l|c|c|c|}
\hline \multicolumn{1}{|c|}{ Material } & $\begin{array}{c}\text { Density } \\
\left(\mathbf{g} / \mathbf{c m}^{\mathbf{3}}\right)\end{array}$ & $\begin{array}{c}\text { Specific surface, } \\
\text { BET }\left(\mathbf{m}^{\mathbf{2}} / \mathbf{k g}\right)\end{array}$ & Average size( $\boldsymbol{\mu m})$ \\
\hline CPC & 3.15 & 1400 & $15-25$ \\
\hline FA & 2.15 & 1200 & $5-15$ \\
\hline SF & 2.20 & 19600 & $0.1-0.2$ \\
\hline
\end{tabular}

\subsection{Methods}

Total experimentation consisted of workability slump test, compressive strength, corrosion potential and linear polarization resistance tests. For workability, the study adopted the use of surface index which is an empirical number which gives more weight to the finer fractions as suggested by Murdock (1960). Thereafter the slump test was conducted with samples from each set. Compressive strength test was conducted on cube with the dimensions of $150 \mathrm{~mm} \times 150 \mathrm{~mm} \times 150 \mathrm{~mm}$ specimens using compression strength 
testing machine (CTM) of $3000 \mathrm{kN}$ capacity. The compressive strength was determined at different curing ages of 1, 3, 7 and 28 days with the addition of $1 \%$ superplasticizers of cement and the average test results were considered for analysis and comparison. The effect of sulfate attack and corrosion of embedded reinforcing steel was studied on three set-up concrete assemblies, cylinders with $15 \mathrm{~cm}$ in diameter and $30 \mathrm{~cm}$ in height, with the two centrally embedded steel bars were casted. Specimens were immersed in a 3.5\% of $\mathrm{NaSO}_{4}$ aqueous solution environment after drying in air for a day in a laboratory atmosphere at temperature of $\left(21 \pm 2^{\circ} \mathrm{C}\right)$ and then weighed. The results of weight loss (WL) were calculated using the equation 1

$$
\mathrm{WL}(\%)=\frac{\mathrm{Wi}_{\mathrm{i}}-\mathrm{Wt}_{\mathrm{t}}}{\mathrm{W}_{\mathrm{i}}} \times 100 \%
$$

Wi is the average weight of triplicate specimens before exposure in grams (g); Wt is the average weight of triplicate specimens after exposure period (g).

For measuring corrosion state or corrosion potentials (Ecorr), high impedance voltmeter was used and recordings were done with respect to a copper/copper sulfate electrode as reference electrode. The linear polarization resistance (LPR) technique was employed to measure the polarization resistance of the specimen. Song and Saraswathy (2007) in their research work successfully measured the polarization resistance of embedded steel in concrete using the same technique as used in work. The test scan used was $\pm 20 \mathrm{mV}$ to indicate polarization resistance of embedded steel in concrete at a scan speed of $\mathrm{mV} / \mathrm{min}$. Basically the set up and the experimentation process and steps are commonly known from principle of electrochemical corrosion of reinforced concrete. This is shown in Figure 2 below: 


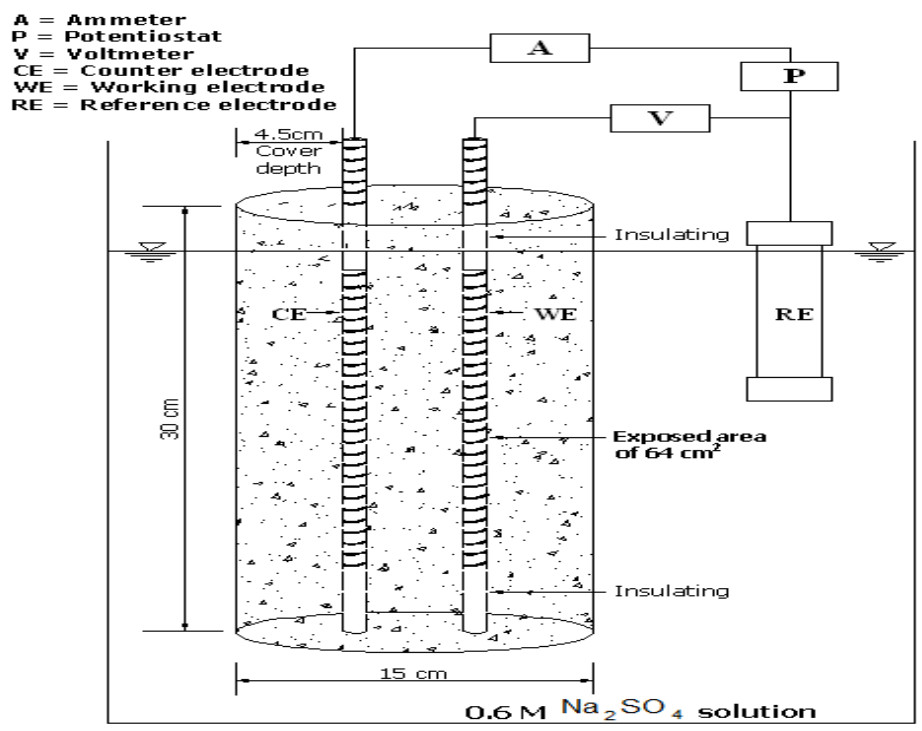

Figure 2 Electrochemical corrosion of reinforced concrete schematic setup for testing LPR [(Dao et al.2010) and (Bentur et al.1998).]

With the use of curves for the potentials plotted against current density, the Rp of the concrete systems in study was obtained.

$$
i \operatorname{corr}=\frac{B}{R p}
$$

Equation 2 of Stern and Geary where B is Tafel constant, it value was adopted and used to calculate the corrosion current density as recommended by various researchers including Dhir et al. (1993); González et al. (1996); Gowers and Millard (1993); Mangat and Mollay (1992). 


\section{Results and Discussion}

\subsection{Workability}

Slump test results were 82, 100 and 110 for concrete mixes without SCM replacement, with $30 \% \mathrm{FA}$ and $10 \% \mathrm{SF}$ respectively. It shows that mixes with $10 \%$ SF produce higher slump than other mixes, 30\% FA mixes was more workable than the mixes with no SCM. A positive effect for silica fume to cause good grading of particles in concrete along with admixtures is significant. Fine particles ranging between150-300 microns reduced internal friction between bigger particles and hence improved workability.

\subsection{Compressive strength test}

Table 8 Compressive strength of concrete with Supplementary Cementing Materials (SCM)

\begin{tabular}{|c|c|c|c|c|c|c|}
\hline \multirow{3}{*}{$\begin{array}{l}\text { Mix } \\
\text { identification }\end{array}$} & \multirow{3}{*}{$\begin{array}{l}\text { No of } \\
\text { specimen }\end{array}$} & \multirow{3}{*}{$\begin{array}{l}\text { w/c } \\
\text { Ratio }\end{array}$} & \multicolumn{4}{|c|}{ Compressive Strength (MPa) } \\
\hline & & & \multicolumn{4}{|c|}{-Age of concrete test } \\
\hline & & & 1-Day & 3-Days & 7-Days & 28-Days \\
\hline $100 \% \mathrm{CPC}$ & 12 & \multirow[t]{3}{*}{0.45} & 11.00 & 22.20 & 29.60 & 35.0 \\
\hline $30 \% \mathrm{FA}$ & 12 & & 13.2 & 23.5 & 30.0 & 37.5 \\
\hline $10 \% \mathrm{SF}$ & 12 & & 15.4 & 27 & 36.2 & 41.0 \\
\hline $100 \% \mathrm{CPC}$ & 12 & \multirow[t]{3}{*}{0.40} & 13.45 & 25.50 & 36.40 & 45.4 \\
\hline $30 \%$ FA & 12 & & 15.9 & 27.5 & 38.2 & 46.0 \\
\hline $10 \% \mathrm{SF}$ & 12 & & 16.2 & 29.2 & 39.5 & 47.9 \\
\hline $100 \% \mathrm{CPC}$ & 12 & \multirow[t]{3}{*}{0.35} & 24.96 & 32.9 & 38.9 & 54.25 \\
\hline $30 \%$ FA & 12 & & 26.55 & 36.20 & 45.10 & 54.50 \\
\hline $10 \% \mathrm{SF}$ & 12 & & 28.20 & 39.6 & 45.50 & 55.50 \\
\hline
\end{tabular}

The compressive strength test results indicate that concrete mix with $10 \% \mathrm{SF}$ has the highest strength in all age of curing in days-. Also, it is observed that the hydration and curing process affects the compressive strength as it increases with increasing curing age as observed in Fig 3 below. 


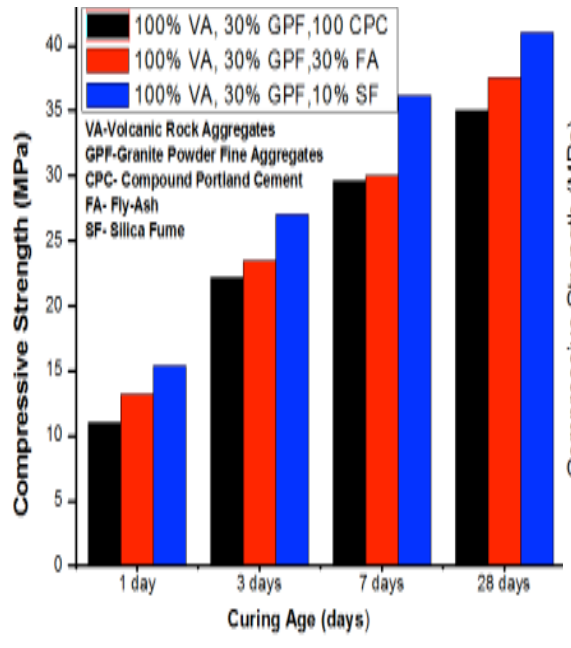

a) $w / c=0.45$

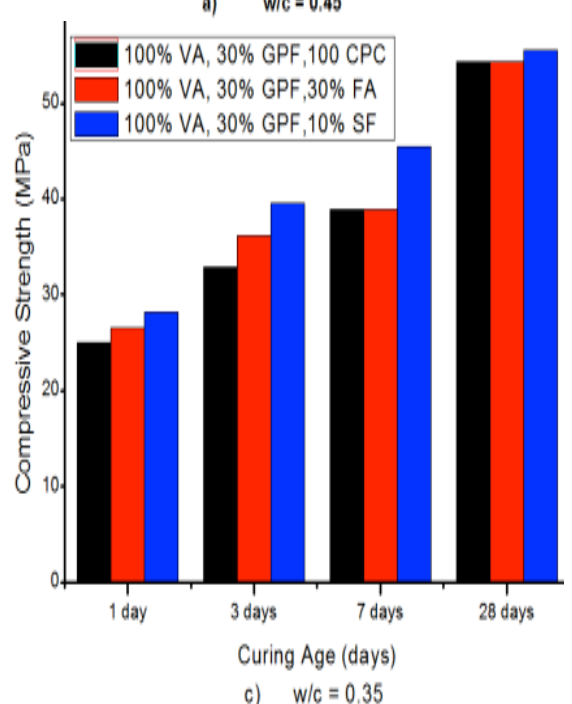

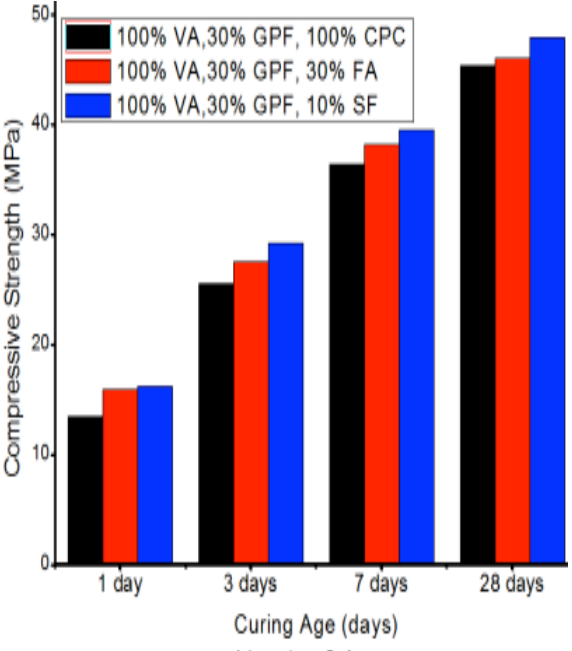

b) $w / c=0.4$

Figure $3 \mathrm{a}, \mathrm{b}$ and $\mathrm{c}$ : Compressive strength with $0.45,0.4$ and $0.35 \mathrm{w} / \mathrm{c}$ ratio respectively.

The figures $3 \mathrm{a}, \mathrm{b}$ and $\mathrm{c}$ show that the lower the w/c used the more the compressive strength the concrete gained in early curing ages. This may be due to reduced aggregate cement transition zone that increases with increase in water-cement ratio. This is because the cement particles are held at a small interval in case of lower w/c ratio than higher w/c ratio. 


\subsection{Concrete weight loss}

The test results of specimen in general show that the concrete specimens lose weight. This was when the weight of specimens after immersed was compared with their weights before immersion in the test solution. It shows that the specimen gained weight on their immersion to solution. Weight loss significantly increased after three months in mixes with no SCM and insignificant increase was observed after four months in the mix with SCM. This was because the expansion products formed after the reaction of the mixed materials filled the pore spaces which makes the concrete system denser and hence increases the weight. Then, the expansion of these products stresses the concrete to the extent of causing fractures in the concrete matrix system, leading to the loosening and loss of the loosened materials, resulting in the reduction in the weight of the specimens

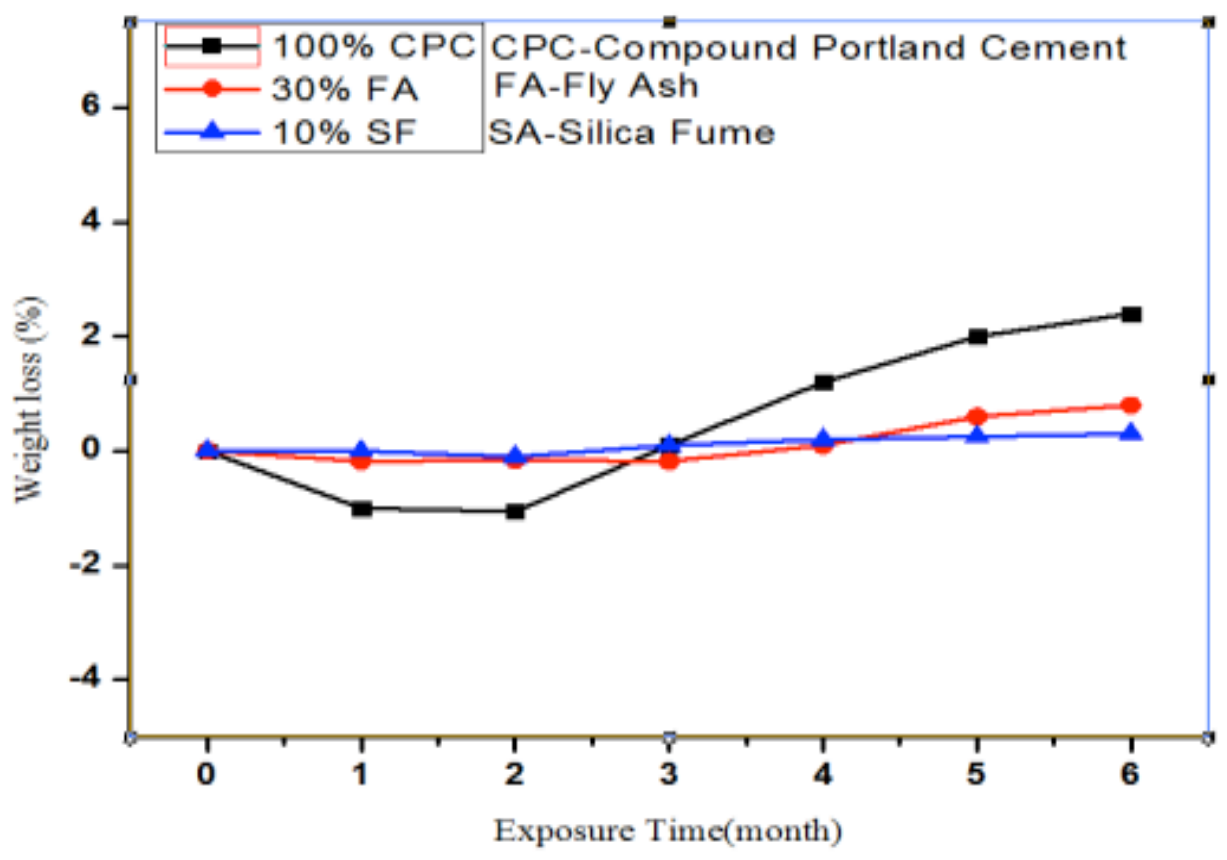

Figure 4 Weight loss of concrete specimen in sulfate

environment 
The maximum weight loss was $24 \%$ duration the six months of exposure of the volcanic concrete mix with $100 \% \mathrm{CPC}$, followed by $0.8 \%$ in the mixes with $30 \% \mathrm{FA}$, The maximum weight loss observed for concrete system mixes with $10 \%$ SF was $0.3 \%$. From these results, it is clear that the contribution of SCM, especially, the concrete with $10 \%$ SF in filling pores of the concrete matrix is significant. The filling of the void in the concrete by the reaction products of the SCMs controls the easy with which sulfate ions penetrate into the concrete.

\subsection{Corrosion potentials}

Figure 5 shows the results of corrosion potentials of the test specimens. The horizontal broken lines corresponds to the corrosion probability as expressed by ASTM C876 (2009) standards. 

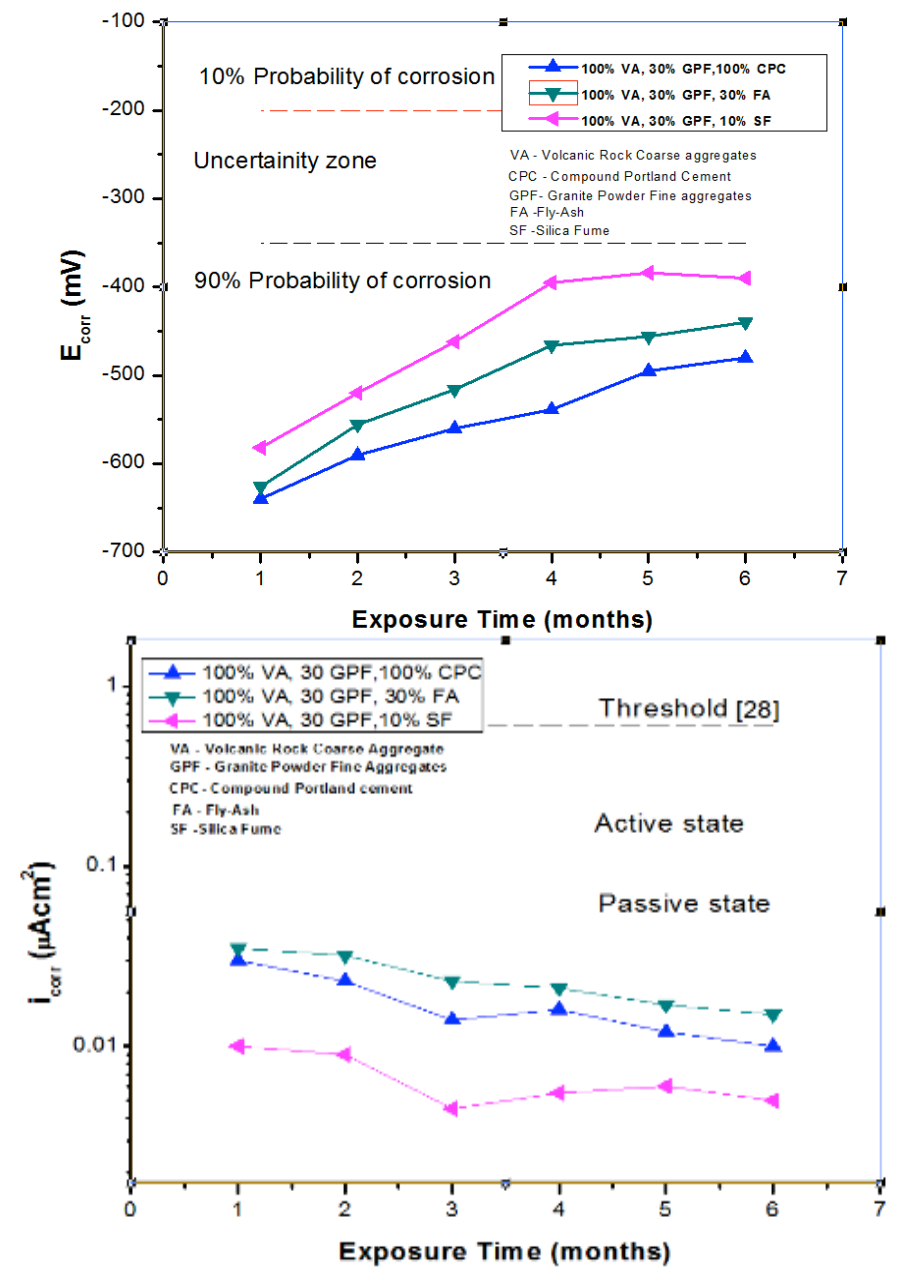

Fig. 5

Fig.6

Figure 5: Corrosion potential of the embedded steel in concrete as a function of the exposure time.

Figure 6: Corrosion current of the embedded steel in concrete as a function of the exposure time.

In the six months of specimen exposure, the corrosion potentials, of all the reinforced concrete systems, show fluctuation ranging from -696 to $-380 \mathrm{mV} / \mathrm{Cu}-\mathrm{CuSO}_{4}$ with a small decrease during the six month, towards more -stable values. According to ASTM C 876, these Ecorr values show that there exists a $90 \%$ chance of active corrosion during all the exposure time; but, the criterion is for partly saturated not totally saturated specimens. ASTM C 876 criterion is applied in fully merged structures or specimen 
environment reinforcement corrosion tests. Therefore, probably all embedded steel were in a passive state during the six months of specimen immersion in the sulfate solution. Otherwise, concrete system with $10 \% \mathrm{SF}$ could have performed better in as far as resisting corrosion of steel reinforcement as shown in fig.6. Since the concrete system with $10 \%$ SF presented the better corrosion potentials during the exposure time. The $10 \%$ SF concrete samples presented corrosion potentials between -520 to $-380 \mathrm{mV} / \mathrm{Cu}-$ CuSO4 compared -696 to $-518.7 \mathrm{mV} / \mathrm{Cu}-\mathrm{CuSO}_{4}$ for $30 \%$ FA concrete systems. This shows that $10 \%$ SF contribution to the inhibition of corrosion of the reinforcement was significant. This testing technique provides qualitative information on reinforcement corrosion. Therefore, quantitative information on reinforcement corrosion could be developed by employing the linear polarization resistance technique presented in Fig.6

\subsection{Polarization resistance}

From the curves of corrosion potential against current density, polarization resistance (Rp) was obtained for all the systems in study and corrosion current density (icorr) was calculated representing the results in Figure 6; the horizontal broken line point out the threshold of active to passive corrosion as was drawn by Andrade and Alonso (1996). In Figure 6; it can be observed that the system steel-concrete that presents the highest corrosion resistance induced by sulfates is the one with $10 \% \mathrm{SF}$, because its corrosive activity was the lowest for all the exposure time as shown in fig.6 and decreased significantly until it reached a lowest level of corrosion $\left(0.0003 \mu \mathrm{A} / \mathrm{cm}^{2}\right)$. The $10 \% \mathrm{SF}$ system showed levels of corrosion between $(0.0001-0.0003) \mu \mathrm{A} / \mathrm{cm}^{2}, 30 \%$ FA ranges of $(0.0001-0.0008) \mu \mathrm{A} / \mathrm{cm}^{2}$ and $100 \%$ CPC showed levels of corrosion range of $(0.06-$ $0.0024) \mu \mathrm{A} / \mathrm{cm}^{2}$. This shows that concrete system with $10 \% \mathrm{SF}$ has more potential to 
reduce the ingress of corrosive agents into concrete when compared to systems with $30 \% \mathrm{FA}$ and $100 \% \mathrm{CPC}$ mixtures. The significant effect this material to inhabit corrosion current density is due to reduction of pores size and pore distribution in concrete system that makes the possible dense structure of pores formed. Because of that, it is deduced that the microstructure of concrete with $10 \% \mathrm{SF}$ becomes denser than the rest of the concrete system mixes. Therefore, it reports a decrease in both sulfate ion penetrability and corrosion current density. According to Powers (1958), several mineral additions have also been shown to improve the resistance of concrete materials to the penetration of aggressive ions. This research intends to contribute to the construction industry material requirement in as regards concrete system with potential to resist sulfate attack and corrosion of steel in concrete.

\section{Conclusions}

The analysis of the primary data collected by experiments and tests on workability, compressive strength, weight loss, corrosion of embedded steel potentials and its linear polarization resistance of concrete systems lead to the hereafter enclosed conclusion. Granite aggregates is an alternative construction material in volcanic concrete system with more chances of improved permeability properties especially when SCMs are used. The use of volcanic rock concrete systems are less costly and environmentally friendly in countries like Rwanda when compared to convention concrete. The use of $30 \%$ FA can increase the compressive strength of the concrete system by $2 \%$ while it increases by $3.23 \%$ when $10 \% \mathrm{SF}$ is used in the volcanic concrete system compared to the use of $100 \%$ $\mathrm{CPC}$ in the same concrete system. Replacement of cement with $10 \% \mathrm{SF}$ and $30 \% \mathrm{FA}$ in concrete reduces around 24 times and 8 times of the concrete weight loss respectively by 
sulfate attack; compared to conventional concrete with no cement replacement. Polarization resistance test has proved $10 \% \mathrm{SF}$ volcanic concrete system to be more resistant to corrosion of steel reinforcement compared to concrete made of $100 \%$ CPC. SCM increased the density of the concrete system and reduced the pore size and distribution in volcanic concrete systems. Therefore, corrosion of embedded steel reinforcement due to sulfate attack in volcanic concrete system can be reduced with the use of SCM than using $100 \%$ CPC. However, superplasticizer $1 \%$ of cement mass could be used to improve workability of the concrete mixture.

\section{Acknowledgement}

The authors would like to thank the University of Rwanda for all kind of support extended to them. Thanks to the Civil-Aid Techno clinic P.V.T. Ltd for laboratory services given to us during our research. Special thanks to the team of civil Engineering students and laboratory attendants who gave us hand in experimentation and other laboratory tests.

\section{REFERENCE}

Abaho G and M. R. Pranesh "Corrosion of steel in embedded concrete with volcanic aggregates due to sulfate attack "IJCIET/07/02/2016/IJCIET_11067.

ACI committee 201, proposed revision of: Guide to durable concrete, ACI Mater. J. 88(2): 1991, pp. 544-582.

Al-Amoudi OSB, Maslehuddin RM, Abduljauwad SN, Influence of chloride ions on sulphatedeterioration in plain and blended cement, Mag. Concr. Res. 46(167), 1994, pp. 113- 123.

Andrade, C and Alonso, C, Construction and Building Materials, 10 (1996) 15.

ASTM International, ASTM C876-09, 2009.

Bentur, A; Diamond, S and Berker, N.S Steel corrosion in concrete, EFN Spon, 7, 1998. 
Dhir, R.K; Jones, M.R.; and McCarthy, M.J. Cement and Concrete Research, 23, 1993, pp.1443.

González, J.A; E. Ramirez, E; Bautista, A; and Feliú, S; Cement and Concrete Research, 26, 1996, pp.501.

Gowers, K. R; and Millard, S.G; Corrosion Science, 35, 1993, pp. 1593.

Hossain K .M. A Properties of volcanic scoria based lightweight concrete. Mag. Concr. Res.56 (2), 2004, pp. 111-120.

Irassar EF, Gonzalez M, Rahall V (2000). Sulphate resistance of Type cements with limestone filler and natural pozzolana. Cem.Concr.Compos. 22(5), 2000, pp. 361-368.

Juenger, M.C.G.; Winfield, F.; Provis, J.L.; Ideker, J.H. Advances in alternative cementitious binders.Cem. Concr. Res, 41, 2011, pp. 1232-1243.

Kalousek GL, Porter LC, Benton EJ Concrete for long-time service in sulfate environment.Cem.Concr. Res. 2(1), 1972, pp.79- 89.

Khalifa Al-Jabri, S; Makoto Hisada, K. Salem Al-Oraimi and H. Abdullah Al-Saidy, Copper slag as the sand replacement for high-performance concrete, Cement \&Concrete Composites,31,2009, pp. 483-488.

L.T.N.; Dao, V.T.N; Kim, S.H; Ann, K.Y. International Journal of Electrochemical Science, 5, 2010, pp.302.

Lawrence C. D, Sulphate attack on concrete, Mag. Concr. Res.4 (153), 1990, pp. 249264.

M. Stern and A. Geary, Journal of the electrochemical society, 104, 1957, pp. 56.

Mangat, P.S; and Molloy, B.T; Materials and Structures, 25, 1992, pp. 404.

Mehta PK, Sulfate attack on concrete: a critical review, Materials Science of Concrete, Ohio. Am. Ceram. Soc. 3, 1993, pp. 105-130.

Murdock. The workability of concrete, Magazine of concrete and concrete research, Nov1960.

Neville, The confused world of sulfate attack on concrete, Cem.Concr.Res.34 (8), 2004, 1275-1296.

Powers, T.C., Structure and physical properties of hardened Portland cement paste. Journal of American Ceramic Society, 41, 1958, pp. 1-6.

Rasheeduzzafar, Dakhil F. H, Al-Gahtani A. S, Al-Saadoun S.S, Bader M. A. Influence of cement composition on corrosion of reinforcement and sulfate resistance of concrete. ACI Mater J, 87(2), 1990, pp. 114-22.

Red DURAR, Manual de Inspección, Evaluación y Diagnostico de Corrosiónene structuras de hormigónArmado, CYTED, España, 1998.

Schittich, C, Building simply two: Sustainable, cost-efficient, local, Walter de Gruyter, Architecture, 2012.

Schneider, M.; Romer, M.; Tschudin,V. M.; Bolio, H. Sustainable cement production: Present and future. Cem. Concr. Res., 41, 2011, pp. 642-650. 
Shi, C.; Fernandez-Jiménez, A.; Palomo, A. New cements for the 21st century: The pursuit of an alternative to Portland cement. Cem.Concr.Re s., 41, 2011, pp. 750-763.

Song, H. W; Saraswathy, V. International Journal of Electrochemical Science, 2, 2007, pp.1. 